\title{
Energy flow analysis and the study of Manihot esculenta Crantz
}

\author{
EMILIO F. Morán \\ University of Florida \\ Gainesville (U.S.A.)
}

\begin{abstract}
This paper makes use of energy flow language. It discusses how this energetics approach can be useful in research having to do with the interactions between man and the environment. All life processes have energy as their common denominator. The paper shows how this methodological approach aids in field preparation, organizes research while in the field and helps in the analysis of data. A discussion of manioc as an essential plant for man in the tropics is presented, and the myths surrounding the plant are indicated and recent research finds put in context. The potential of manioc as a food of the future is presented and suggestions are made for an energetics approach to the plant in situ. The plant's potential needs to be studied in the context of the real world in which tropical man utilizes it. Energetic models are presented as guides to the study of the plant as a system producing food.
\end{abstract}

\section{THE ENERGY FLOW APPROACH}

A study of the relations between man and the environment is a study of systems. The system of nature is a system of energy flows in which certain natural compartments capture the dispersed solar energy and utilize this energy for self-maintenance and growth. Likewise, man's Culture is a system. It is a premise of cultural ecologists (') that man's primary adaptive system - Culture - has taken shape in response to the need to more efficiently collect the energy captured by nature's systems. The man-environment relation is mediated by the cultural system. Social structure evolves guided by the drive to provide effective use of the energy sources available in a given ecosystem (Cohen, 1968). Or, in the words of Leslie White (1949) : "it becomes the primary function of culture to harness and control energy so that it may be put to work in man's service".

Biotic communities gather food and distribute energies within the social system to assure self-maintenance and growth. To trace these energy flows - from nature to man and back to ecosystem - is the task of cultural ecology and is the basis of the methodology suggested in this paper. One reason for the lack of a systems methodology in cultural ecology is the general neglect of anthropologists for the connotations of quantification. An essential aspect of systems analysis is the diagramming of models. The implication of much modeling is that numbers will eventually be included and the system analyzed quantitatively. While the social sciences have not reached the stage that all important variables can be accurately quantified, there is much in cultural ecology that lends itself to ready quantification if the anthropologist is willing to take careful measurements and cooperate with other disciplines (e.g. biology, agronomy. engineering) in obtaining them.

Modeling languages are many. Energy flow language (Odum, 1971) developed in departments of environmental engineering and is an attempt at summarizing previous modeling approaches as a simpler, more comprehensive language. It is well-equipped to deal with environmental data, as results indicate (cf. Odum and Pigeon, 1970). Energy flow language, as all human languages, is always in process of development as it finds ways to express new concepts that it needs to use.

Energy flow language is holistic in approach, while acknowledging its inability to

(1) Cultural Ecology is the branch of Cultural Anthropology that studies the interrelation of man and environment. 
quantify holistically - due to the complexity of variables. Energy flow languages explains process visually through qualitative diagrams. In this characteristic is one of its strengths. A good description - either biological or anthropological - is often lengthy and the reader may not quite be able to sift the essential from the subsidiary. A good test of the clarity of a description, and of the grasp of the essential processes, could be the ability to describe the essential in a whole systems model. Energy modeling can sharpen our understanding of a system by forcing us to focus on the impact and direction of process.

To anyone that has attempted ecological systems analysis one fact becomes blatantly clear - there has been no true holism in research. Every field contributing to the understanding of man has been "short-circuiting" the process, either leaving out important factors or referring to them in vague generalities that enlighten little, even when they sound good or give us ideas about what is happening.

What are the advantages of modeling before undertaking field research? It forces us to maximize our understanding of the society to be studied before we go looking at "anything that can be found" by placing data in terms of its role in the system. By postulating certain flows in a man-nature system, we have a ready contrast, or confirmation, between the assumed and the perceived. Perhaps more importantly, we have defined what compartments we know need measuring and in what units. Other compartments, not in our pre-field model, may emerge as important. This would lead to the important element of model-modification in the field. A model is just a summary of what is known about a system. Pre-field models are a summary of the knowledge available in the literature. Field experience, of necessity, leads to modifications to the preliminary model.

The advantages of energy flow language in cross-cultural comparisons are many. For example, a diagram of shifting agriculture (see diagram 1) will look more or less the same in most societies - differences lying in the details and the quantified sontent of the flows. In this manner we car! begin to isolate the "forcing functions" - the factors that account for the differences - and isolate causal factors. The discovery of causes will be a significant contribution to understanding of a culture and its enviromment. It will also expand our ability to make more generally applicable statements about man in the ecosystem, what variables seem to be at the root of the differences: kilocalories spent per square meter per day (labor inputs), the nature of the soils, the rainfall pattern, the drainage, the method of burning the fields, the timing of burning, the presence or absence of weeding, ritually accented vís-a-vís ritualiy indifferent activities or any combination of the above.

\section{ENERGY FLOW LANGUAGE}

This language is one of many systems languages. It describes energy availabilities, causal actions, storages, pathways of control, and multiplier actions. Also, energy flow language implies a mathematical role for the symbols that it uses, so that one can superimpose known, or estimated flow values, storage, and multiplier effects upon the diagram. This diagram can then be translated into analog language and simulated or programmed into a digital computer or hydrids (Lugo et alii, 1971). From simulation it is possible to learn, over time, the growth and decline of the various parts, and their relationships to each other within the system.

A whole systems approach making use of energy flows involves a three-step procedure. First, one develops diagrams that contain what is thought to be important and the interrelationships among these elements. Second, one identifies sample studies that provide numbers suggesting the magnitude of each mathway and module. If no data exist, the need for such is indicated. It is now that the researcher notes the kinds of measurements and units that be must collect in the field. Third, one employs simulation. No doubt, simulation can be a tedious business. However, its usefulness for making a rough identification of the effect of one compartment upon another cannot be denied. The goal is to refine the model so that it is both a good expression of the system and useful in the identiifcation of interrelationships within this system. There is 


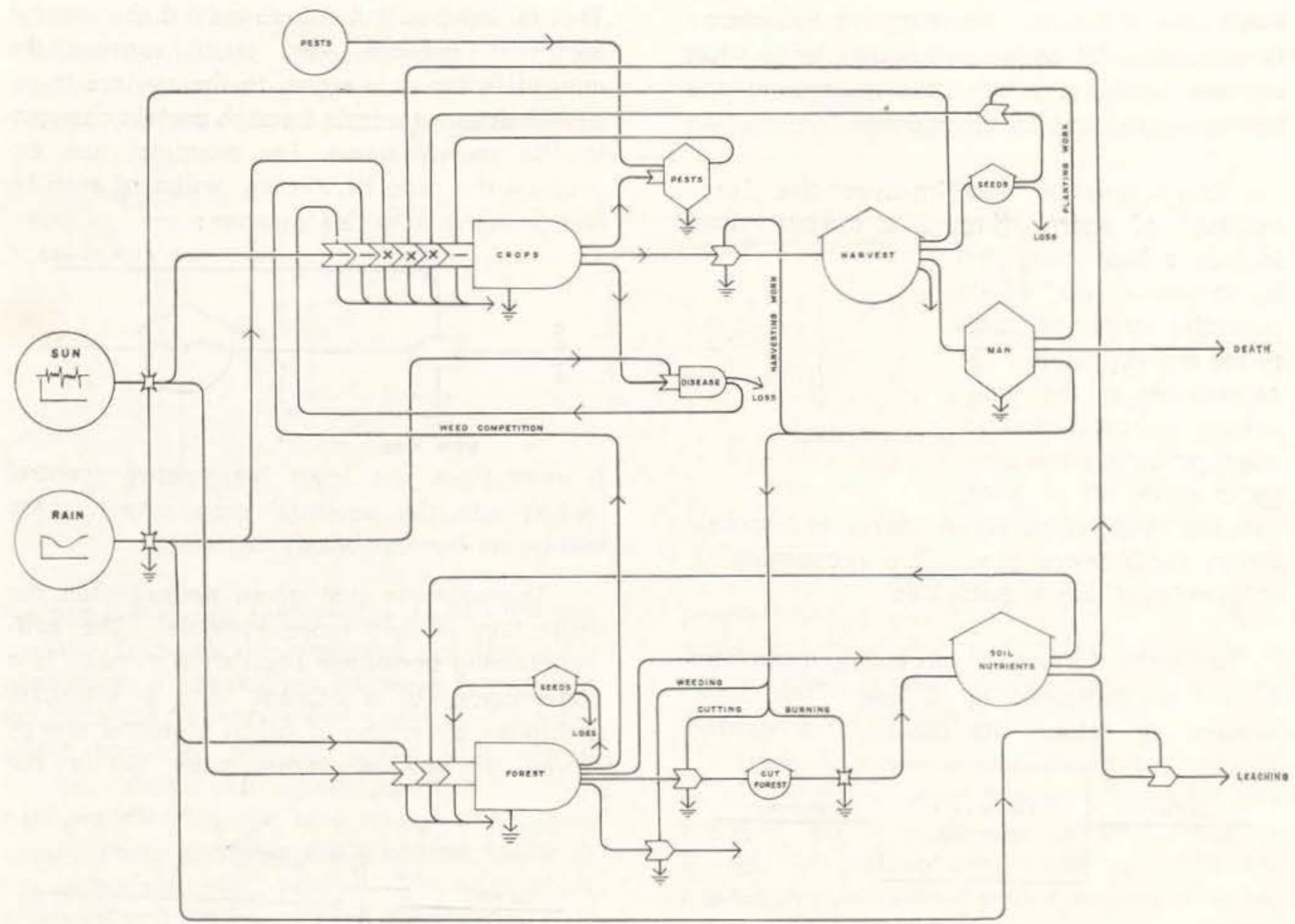

Diagram 1 - Generalized slash-and-burn agriculture model

no need to emphasize that a diagram is a useful tool for expressing what is understood, both really and hypothetically, ajout a system's operation.

To use this approach one needs to know both the morphemes of flow language and the rules that link the symbols together.

Everything that occurs on earth involves a flow of potential energy from some source (e.g. the sun, fossil fuel, cities viewed as migration pools, foreign markets). The source

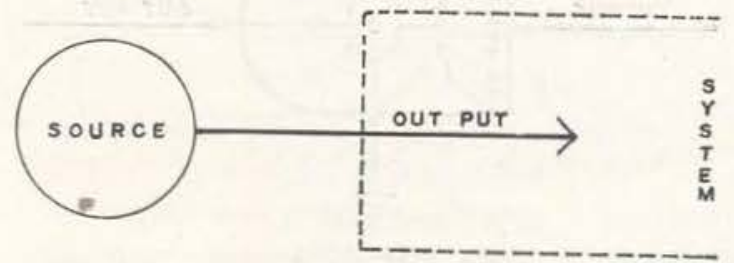

is understood to be "outside" the system under consideration but the output from the source is evaluated. Energy from the source moves through pathways driven by forces that originate in storages. In energy network diagrams,

flows move from sources that are usually drawn going from left to right along pathway lines. No arrow is used if there are forces

pushing from both directions. The valve is

used if backforces push but backflow is prevented.

A passive storage shows the location within a system of actions such as moving potatoes into a store, fuel into a tank, accumulation of litter on the forest floor, ash depo-

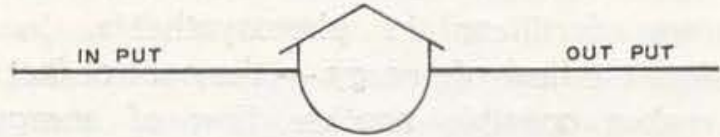


sition after the burn. No new potential energy is generated by action and some work must be done by some other unit in moving the energy in and out of the storage.

Every process that involves the "processing" of energy through a system must include a heat sink, that is, an "energy tax" of the potential energy necessary for any operation. The second law of thermodynamics indicates that in every process, some ener. gy is given off as heat.

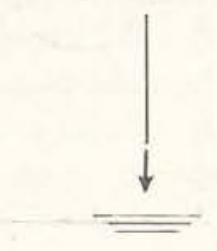

HEAT SINK
Use and reuse of potential energy is impossible in earth processes. This processing is unidirectional due to such loss.

Unspecified functions not having a standard symbol are indicated by a box. The box's function or rather, its identity, is written

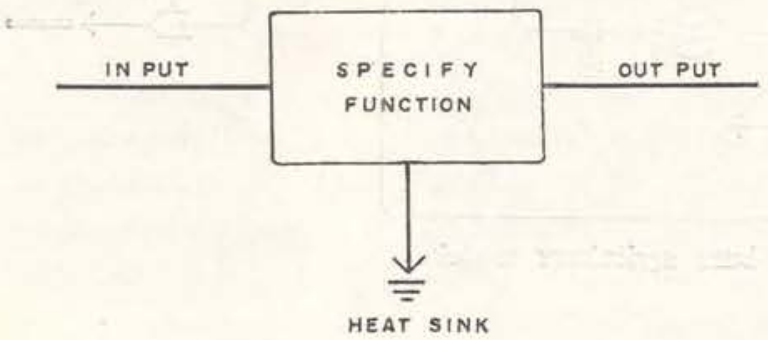

within the box. The use of the black box is common both in cases when we do not wish to fully explain its inner workings in a particular model and when we do not understand its inner workings but wish to account for its part in the system.

The workgate module can express as simple an action as a person turning a valve, as well as processes such as the action of a

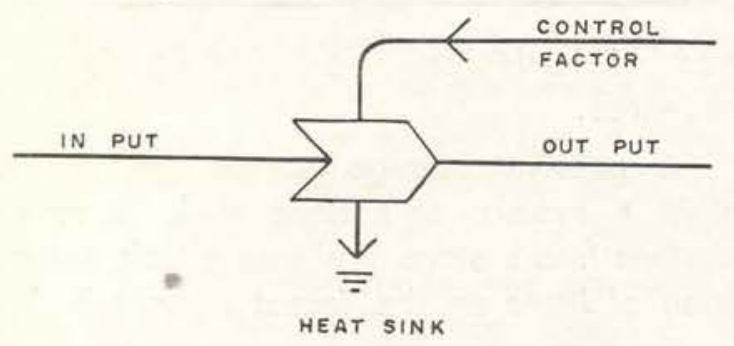

limiting fertilizer in photosynthesis. In a workgate a flow of energy - the control factor - makes possible another flow of energy.
That is, input-output occurs only if the control factor is present. One could express the control factor as a signal to the system to reestablish homeostasis through certain changes in the energy flows. For example, one expresses the crop harvesting action of man by diagramming it in this manner:

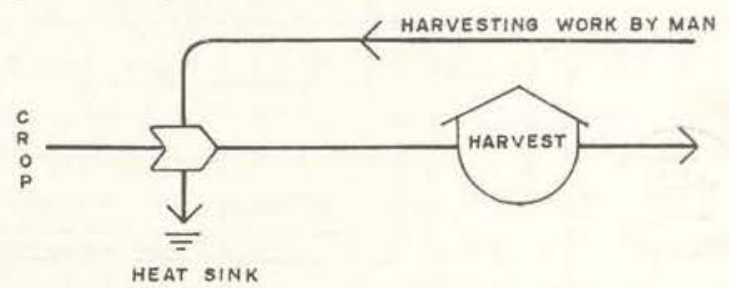

If man does not input his energy (control factor) into the potential crop output, there will be no harvest input.

The example just given necessitates the indication of two more symbols. The selfmaintaining consumer population symbol is a combination of a storage and a workgate multiplier, by means of which potential energy stored in one or more sites within the

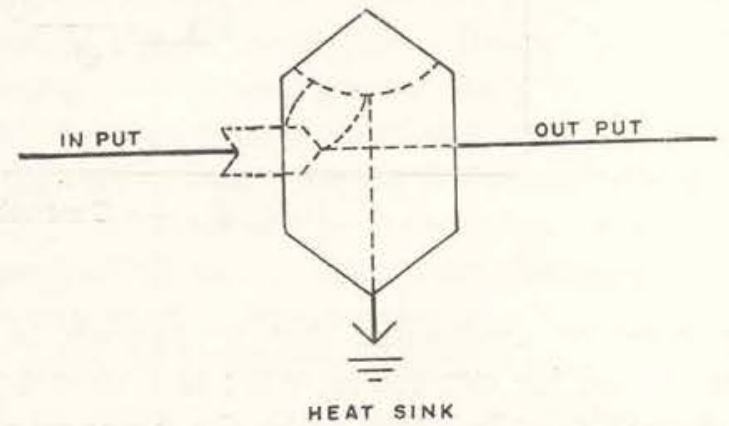

subsystem is fed back to work upon the selfmaintenance and growth of that unit. This module includes animal populations ranging from the unicellular to man and his cities and industries.

The plant population module combines the consumer unit described above and a "pure

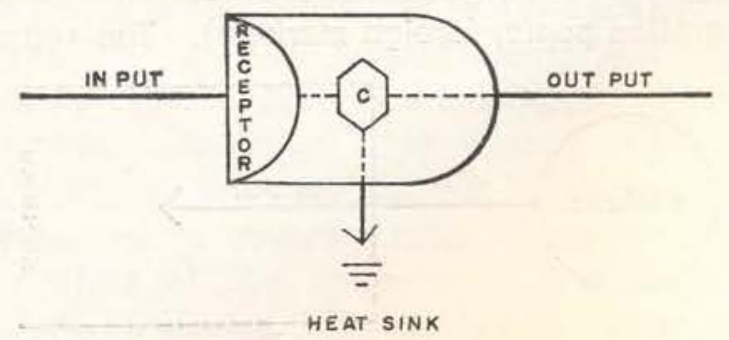

energy receptor" - a unit that receives pure wave energy such as sound, light and water waves, and then processes this wave energy 
in combination with some cycling material to produce an energy activated state. In this unit the pure energy is passed to the consumer subunit, which by its functioning maintains the working of the receptor, and which is itself maintained and kept growing. The green plant is an example of this unit. The previous example can now be expresed more completely:

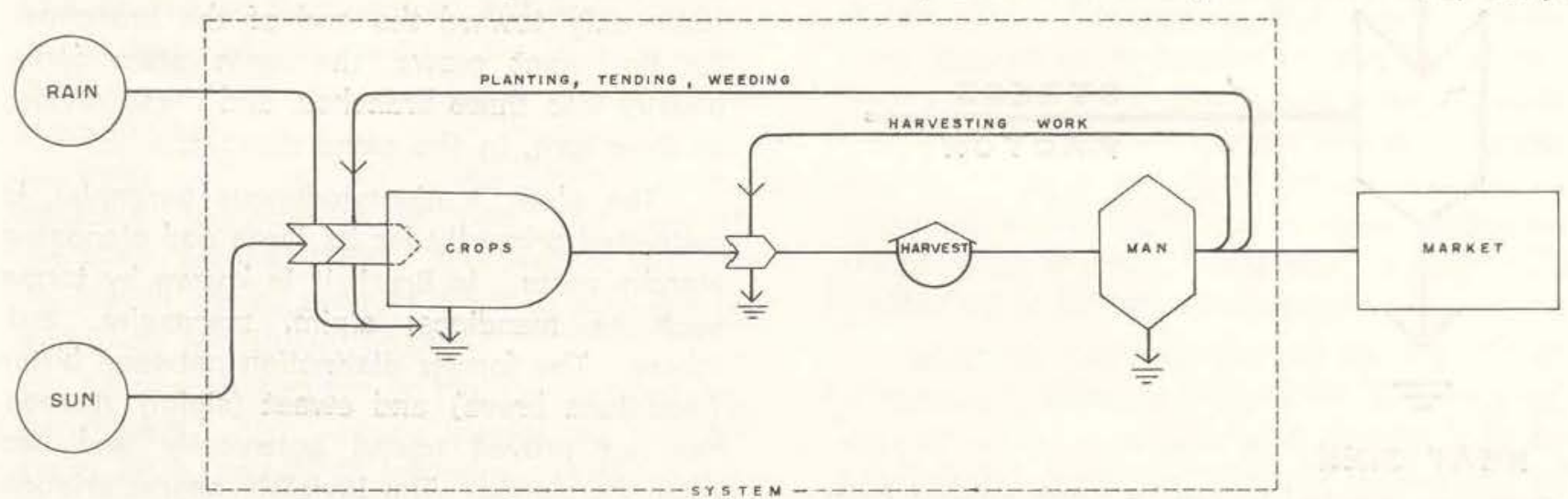

The sun's rays and the rain (to name only two climatic factors) are received by the plant population, which utilizes the wave energy and the moisture to respire and grow. This growth would not take specific shape (e.g. beans, manioc, squashes) unless man had spent energies clearing the land and planting such crops. These energies are a control factor in the output of, say, manioc. The respiration (metapolism) and growth of manioc involves heat losses (energy sinks). The crop output could not become harvested and serve as an input of food to man without man's harvesting labor (control factor), which also has a multiplying effect, as the amount of energy spent by man is considerably less than the energy derived from the harvested crop biomass. Once harvested, the crop is stored and used by man as needed, with some of it being sent to market, which in this case is kept outside the system under consideration.

A whole systems approach must consider that in some societies man engages in economic transactions involving money. The

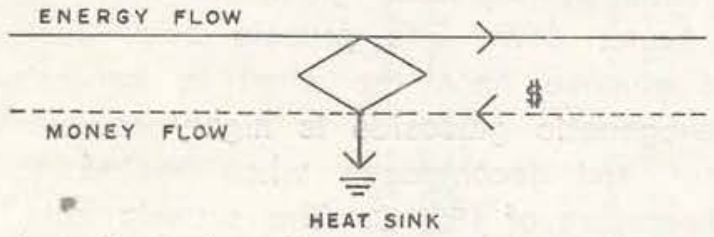

broken line describes the money flows involved. The unbroken line describes the energy flows. Money flows in the opposite direction to the flow energy, and the concept of price proportionately adjusts one flow to the other. Equivalencies of goods vary from situation to situation, but in each case the goods-for-money exchanges are indicated.

Under certain circumstances in energy processes there are on and off conditions. For example, on a given plot of land under a system of shifting agriculture a symbol is needed to indicate that after a number of years, say three, the farmer will move to another piece of land. Thus, the land is "on" for three years, then it is "off"-for the fallow period (unless we are interested in studying the rate of secondary sucession in which case it is "on" but differently. This on-off situation is indicated by a switch symbol. It is used

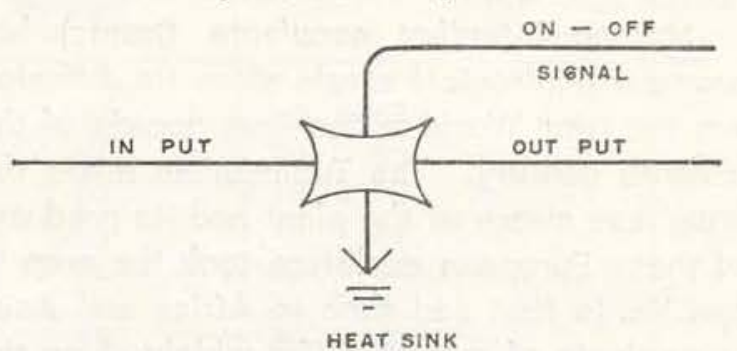

for flows that have this simple dual state. Many actions of man and nature are of this type (e.g. voting, reproduction, starting a car, position, activities of particular interest).

The last symbol that we will present here is the stress module. It defines the drain of energies from a flow. When a system is stressed, the potential energy that was available to do work is lost. The stress symbol is, 


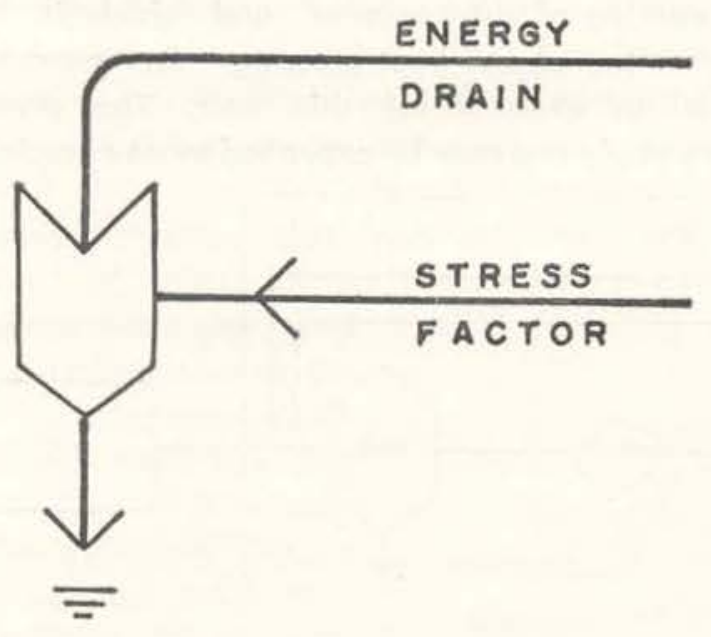

HEAT SINK

then, an inverted workgate, with energy from the system being drained into a heat sink by an environmental or social stress factor, shown in the diagram on the opposite side of the workgate. Erosion is one of the most common types of stress. Noise levels, pace of life and others can be stress situations.

Energy flow diagrams briefly and clearly state the process of energy flows from sources to storages and consumers, as well as the loopbacks necessary for continuous process. Making these diagrams helps us organize our concepts and our data by forcing us to develop energy flow circuits and controls that connect modules and make up the network.

\section{MANIHOT ESCULENTA AS A SYSTEM}

Manioc (Manihot esculenta Crantz) has become a pantropical staple since its diffusion from the New World in the first decade of the sixteenth century. The Tupinambás made the Portuguese aware of the plant and its products and these European explorers took the crop to Cape Verde first and then to Africa and Asia. The products of manioc differ widely since the Portuguese were only partly aware of the various processes practiced by the aboriginal population. The available data is "shockingly fragmentary", and is chiefly taxonomical in character. Fn understanding of manioc as a system, producing food, is generally lacking.

The manioc plant is assigned to the genus Manihot and to the family Euphorbiaceae. This woody shrub grows on the average to a height of 5 to 12 feet - though it has been known to attain 18 feet (Jones, 1959). The leaves are large and palmate, ordinarily with five to seven lobes, on a long, slender petiole. The leaves grow only toward the end of the branches. As the plant grows, the main stem forks. usually into three branches, and these divide, in their turn, in the same manner.

The plant, a dicotyledonous perennial, is cultivated primarily for its large and elongated starchy roots. In Brazil it is known by terms such as mandioca, aipim, macaxeira, and others. The former distinction between bitter (mandioca brava) and sweet (aipim) manioc has not proved useful botanically and has been abandoned. The invisible characteristics thought to indicate the toxicity of the root vary from place to place, and all manioc is now regarded as varieties of Manihot esculenta (or utilissima Pohl).

Fresh manioc is primarily a source of carbohydrates and contains very little protein or fat. It is rich in Vitamin C and calcium, with significant amounts of thiamine, riboflavin, and niacin. Much of these nutrients are lost in certain processes. Unfortunately, not many of the processed manioc products have been analyzed.

Manioc contains a toxic element, prussic acid, which varies from harmless to lethal depending on the amounts of acid present. A root is "sweet" if it contains less than 50 $\mathrm{mg}$ of prussic acid per $\mathrm{kg}$. of flesh, and bitter if over $100 \mathrm{mg} / \mathrm{kg}$. (Bilhous, 1952). Differences in prussic acid have been found between tubers in the same field. The living plant contains no free prussic acid, but like most members of the Euphorbiaceae family, it exudes a latex from small sacs located just beneath the peel or bark when it is cut or bruised. The latex contains cyanogenetic glucoside that begins to break down into prussic acid, acetone and glucose once the plant is harvested. Cyanogenetic glucoside is highly soluble in water and decomposes when heated to a temperature of $150^{\circ} \mathrm{C}$. The prussic acid is freed by the action of an enzyme, linase, that is present in the plant. Hydrolosis under the influence of linase can be accelerated by soaking the roots in water, by cutting and by 
heating. If temperature is allowed to rise above $75^{\circ} \mathrm{C}$. the linase is destroyed and some of the glucoside may not be hydrolized, It was thought at one time that poisonousness was associated with variety and appearance. It has been shown recently by Bilhous that the correlation is extremely loose and unpredictable. Prussic acid content varies markedly with growing conditions, soils, moisture, temperature, altitude, and age of the plant (Jones, 1959). The prussic acid of the leaves can be brought down to safe levels by boiling for fifteen minutes.

Manioc cultivation is largely confined to the tropics. Approximate boundaries can be set at $30^{\circ} \mathrm{N}$. and $30^{\circ} \mathrm{S}$. latitudes It does best at temperatures near $65^{\circ}$ Fahrenheit. It shows lack of resistance to cold, its growth stopping at $50^{\circ} \mathrm{F}$. and dying by frost. Manioc produces best in areas of abundant rainfall, while surviving drought conditions. It grows well on soils ranging from sands to clays. It appears to be able to survive on any soil that does not become water-logged.

Manioc is usually planted from cuttings.
After the field is burnt, the stalks are introduced into the ground. The cuttings usually chosen come from the center portion of the main stalk and are typically six to twelve inches long. Spacing of the cutting varies from population to population but never less than one yard apart from each other. Yields compare favorably with those of other starchy staples. Five to ten tons per hectare can be expected, using traditional tropical methods. Under experimental conditions. manioc has yielded up to 65 tons per hectare.

As staple food, manioc has been criticized on several counts: soil depletion, soil erosion, ease of growing, prussic acid content, and its nutritional deficiencies. Three of these negative points can be corrected by direct action: leaving stems and leaves in the field, covercropping and manuring; erosion can be arrested by intercropping and contour ridging; prussic acid content can be reduced to safe levels by soaking and heating. Ease of cultivation appears to be more of an asset than a liability. The table below gives the amino acid profile of manioc leaves.

\section{TABLE I}

Amino Acid Profiles for Manioc Leaf Protein (Per cent, $16 \mathrm{~g}$. nitrogen basis)

(cf. Rogers and Milner, 1963: 215)

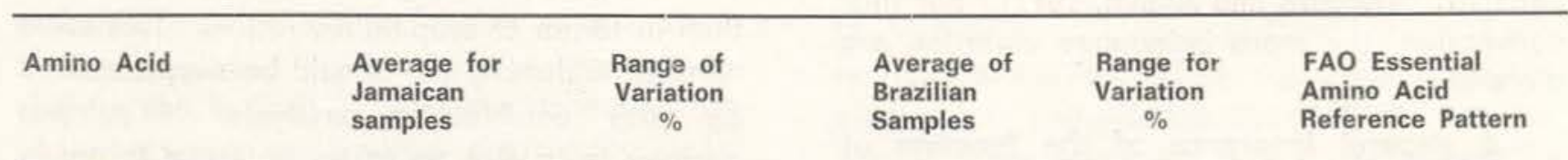

\begin{tabular}{|c|c|c|c|c|c|}
\hline Alanine & 5.98 & $5.66 \cdot 6.39$ & 6.19 & $5.22-6.66$ & $\ldots \ldots$ \\
\hline Arginine & 5.28 & $4.00-6.80$ & 6.12 & $5.30-7.35$ & $\ldots \ldots$ \\
\hline Aspartic Acid & 10.14 & $9.49-10.72$ & 9.63 & $9.10-10.53$ & $\ldots \ldots$ \\
\hline Cystine & 1.37 & $1.04 \cdot 1.99$ & 1.04 & $0.74-1.47$ & $\ldots \ldots$ \\
\hline Glutamic Acid & 10.22 & $9.37-11.83$ & 10.12 & $8.80-11,02$ & $\ldots \ldots$ \\
\hline Glycine & 5.39 & $4.29-5.95$ & 5.32 & $4.94-5.58$ & $\ldots \ldots$ \\
\hline Histidine & 2.23 & $1.44-3.28$ & 2.56 & $1.48-3.40$ & $\ldots \ldots$ \\
\hline Isoleucine & 5.01 & $4.85-5.26$ & 4.84 & $4.34-6.31$ & 4.2 \\
\hline Leucine & 8.89 & $7.66-9.67$ & 8.85 & $8.33-9.47$ & 4.8 \\
\hline Lysine & 7.20 & $6.00-8.24$ & 6.33 & $5.60-7.82$ & 4.2 \\
\hline Methionine & 1.65 & $1.39-1.84$ & 1.71 & $1.51-2.00$ & 2.2 \\
\hline Phenylalanine & 5.82 & $5.06-6.39$ & 5.53 & $5.11-6.65$ & 2.8 \\
\hline Prolibe & 4.64 & $4.12-6.14$ & 5.40 & $5.12-6.40$ & $\ldots \ldots$ \\
\hline Serine & 5.16 & 4.74- 5.81 & 4.60 & $3.58-5.56$ & $\ldots \ldots$ \\
\hline Threonine & 4.92 & $4.70-5.14$ & 4.73 & $4.49-5.08$ & 2.8 \\
\hline Tryptophane & 1.47 & 1.28- 1.69 & 2.07 & $1.56-2.50$ & 1.4 \\
\hline Tyrosine & 4.18 & $3.74-4.82$ & 3.93 & $3.71-4.08$ & $\cdots \cdots$ \\
\hline Valine & 5.73 & $5.30-6.22$ & 5.58 & $5.34-6.64$ & 4.2 \\
\hline
\end{tabular}


Manioc leaf protein is clearly deficient in the amino acid methionine and marginal in its contents of tryptophane. However, it exceeds in all other essential amino acids, a pattern similar to that of the soy bean, which is usually considered among the best in so far as nutritive value of readily available vegetable protein (Rogers and Milner, 1963).

The products from manioc are highly acceptable to the palates of tropical peoples, as its quick diffusion would indicate. It is not sound application of science to try to systematically change the diet patterns of over 250 million people, workdwide, even if it were possible, especially when the alternatives may be worse - cereal grains yield less colories per unit of land, require a higher input of labor, and require more of the soil. In other words, manioc can free tropical peoples to devote more of their energy to the obtention of highquality protein, rather than spend it on cereals. It now seems that manioc may be able to generate protein-rich human food. "By improving the indigenous cassava fermentation methods being practiced now in Africa and South America, products with as much as thirty-three percent protein on a dry weight basis can be generated which will not only by acceptable to the palate but also be inexpensive." (Rogers and Appan, 1971). For this conversion, the more poisonous varieties are preferable.

A general ignorance of the function of manioc in the cultivation-utilization complexes (the system) of tropical areas accounts for the bad reputation of manioc. Even in Brazil, where its importance in the Amazon and elsewhere is recognized, research is restricted to a couple of experimental stations (Albuquerque, 1969).

Manioc has been blamed for causing kwashiorkor in Africa. The alleged nutritive deficiences of manioc have been grossly overstated and recent research sheds considerable light on manioc's true potential as food. The tuber is primarily a supplier of calories. When eaten in conjunction with other foodstuffs, it provides an excellent diet.
Rogers and Appan (1971) have shown, using systems analysis, how manioc could turn out to be an important crop in an ecologically deteriorating world. 'The scarcity of capital in "underdeveloped" nations is a principal obstacle to the transformation of those countries to the "new agriculture". The technological revolution in its turn, tends to use agents of pollution which tend to deteriorate the environment, so that these nations are caught in a vicious circle of either economic improvement or ecological deterioration. It is in this context that systems with potentialities of efficiently generating nourishment from depleted or disrupted environments, under primitive conditions of economy and technology (due to absence of capital) are bound to grow in importance.

The potential of manioc is outstanding (see diagram 2 on next page) for its rugged ecological adaptations: tolerance to drought, aggressiveness towards pests and weeds, its capacity to grow in widely varying levels of $\mathrm{pH}$ and soil structure, its high biological efficiency as a high producer of calories and its ability to survive in poor environments.

Description of agricultural systems should begin with essential data about agronomic techniques and management practices. Rather. than in terms of crop-fallow ratios. This solid agronomic description should be supplemented by crop combination analysis. If cultural ecology is to live up to its potential it needs to do research which is less impressionistic and more basic. Thus, pure concentration on the social relations of a group, which fills volumes in anthropological writing, leaves little time to look at the energy flows through a natural system and labor and capital inputs involved so that conclusions can be arrived at: how the environment shapes human cultura! adaptation and vice versa. What is being suggested here is that in land-use studies, the main task is the unified treatment of economics and ecology. This permits determination of ecosystem carrying capacities at given technological levels as well as the optimal adaptive techniques. 


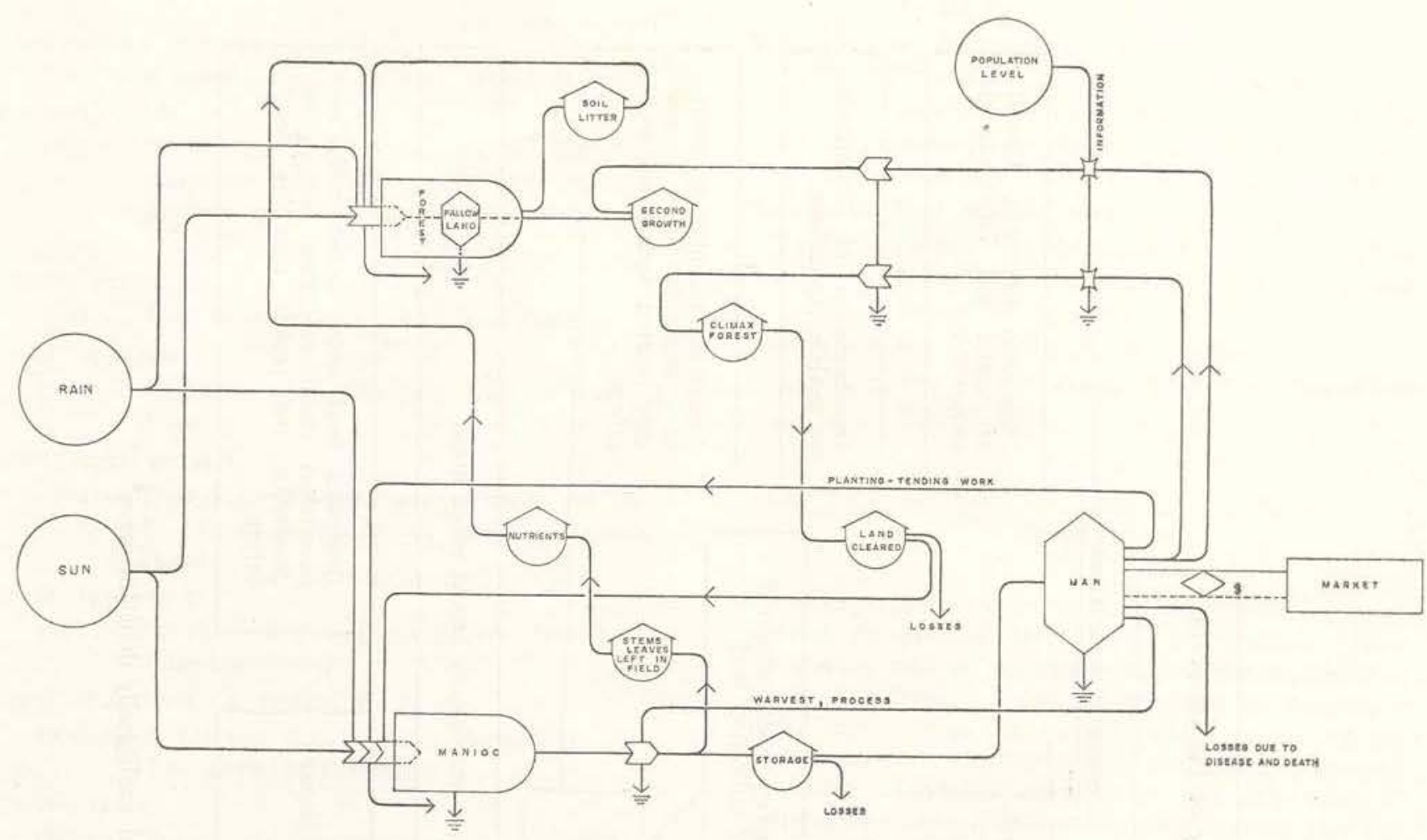

Diagram 2 - Generalized model for the study of Manihot esculenta Crantz

This need is fulfilled by energy flow modeling. Both economic and environmental data can be included in one whole model which can be quantified as necessary. Before further research on manioc occurs, models of this sort may help in ordering the priorities of research and looking at manioc as a system - the plant and its relations to the sun, to climate and to man - who has depended for centuries on it for tropical sustenance. On the next page is a suggested general model for studying manioc in context. The model will require extensive modification according to the context in which it is being studied (e.g. experimental station, shifting cultivation, large commercial farm) and the values of the flows will differ according to soil conditions, nutrient availability and other causes. A great deal of socio-cultural data - agricultural patterns needs to be gathered in its adaptive significance, As the bibliography of this paper only begins to indicate, there is much work on manioc already available. Most anthropologists going to the tropics hardly become acquainted with this rich data. A great deal of naively er- roneous information and urderstandings come out of anthropologists' pens. One has just to ask an agronomist what he thinks of most of this data to discover that it tells him nothing useful about man's relations to crops. The technique suggested here can be put to instant use. In Anthropology, biological sciences and agronomy the method of energy flow analysis summarizes and clarifes the obscure. And for any of these scientists it is probably best to sit together and formulate a composite whole systems - diagram of what is important in understanding man's relation to plant and animals.

An energy flow approach is not a panacea for mediocrity. The researcher still holds it in his power to do a good or a bad job with his goals. But this method of analysis lends a simplifying character to the organization of data before, during and after field work, while permitting precise description enhanced by processual understanding. It is hoped that the application of this approach grows in the biological and sccial sciences. 
TABLE 2

The two major constraints limiting the capability of the biosphere

in generating nourishment to support mankind.

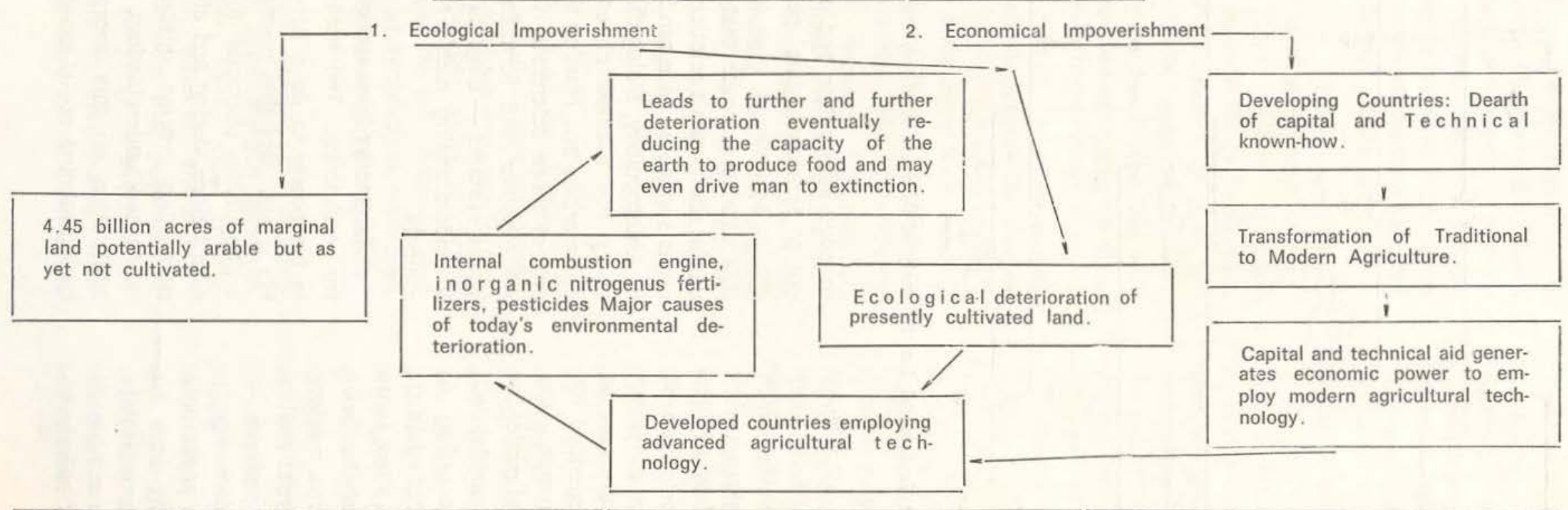

Systems capable of generating nourishment from economically and ecologically impoverished areas

More and more marginal lands can be
brought under cultivation, thus supple-
menting food resources.

"Manioc's potential as a food generating system under conditions of poor capital resources and ecologically deficient areas". 


\section{LITERATURE CITED}

ALbuquerque, MiLton de

1969 - A mandioca na Amazônia. Belém, SUDAM.

BolmuIs, G, G.

1952 - ' "L' emploi de la reáction par la couleur de Guignard dans la sélection du Manioc". Revue International de Bot. Appl. d'Agric. Tropical (Nov.-Dec.): 560-563.

COHEN, YEHUDI

1968 - Man in Adaptation. Chicago, Aldine.

JONES, WILLIAM

1959 - Manioc in Africa. Stanford, Univ. of Stanford Press.

LUGO, ARIEL ET ALII

1971 - Models for Planning and Research for the. S. Florida Envi-onmental Study. Gainesvile, Florida.

ODUM, HOWARD T.

1971 - Environment, Power, and Society. New York, Wiley-Interscience.

ODUM, HOWARD T. \& PIGEON, R. F. ED.

1970 - A Tropical Rain Forest. Springfield, Va., U.S. Dept. of Commerce.

ROGERS, D. J.

1963a- "Studies of Marihot esculenta Crantz and related spzcies" Bull. Torrey Bot. Club. $90: 43$.
$1963 b$ - "Cassava leaf protein". Economic Botany, $13: 261-263$.

ROGERS, D. J. \& APPAN, S. G.

1971 - Cassava-based nourishment generating system capable of functioning in ecologically and economically impoverished areas". Tropica Root and Tuber Crops Newsletter, 4:13-18.

Rogers, D. J. \& MHLNer, MAX

1965 - Amino Acid Profile of Manioc Leaf Protein in relation to nutritive value. Economic Botany, 17:211-216.

WHITE, LESLIE

1959 - The Evolution of Culture. Now York, McGraw-Hill.

\section{RESUMO}

A importância da mandioca como alimento essencial do homem no trópico é discutida, considerando-se não só os mitos, mas também recentes fatos científicos. O estudo do fluxo de energia é feito com vistas às necessidades potenciais da planta no contexto do mundo real onde o homem a utiliza. Modelos energéticos são apresentados como guias para o estudo da planta como um sistema produtor de alimento, e demonstrando como esta metodologia pode auxiliar na organização de pesquisas e na análise de resultados. 